\title{
SOUNDS ELISION BY TAIWANESE UNIVERSITY STUDENTS IN PRONOUNCING ENGLISH PHRASES
}

\author{
${ }^{1}$ Ihsan Tanama Sitio, ${ }^{2}$ Rahmadsyah Rangkuti \\ ihsantsitio@gmail.com, rangkuti@usu.ac.id \\ ${ }^{1,2}$ Faculty of Cultural Studies, University of Sumatera Utara
}

\begin{abstract}
The study aims to figure out the phonological variations of sounds elision realized by Taiwanese university students in pronouncing several English phrases. Eight native Taiwanese students were chosen to support the analysis of the study. They consisted of 8 males and 8 females from the college of humanities and literature of Chung Chen University and from the faculty of foreign languages of Asia University, Taiwan. The study used a descriptive qualitative design. According to Ary, Jacob and Sorensen (2010), qualitative researchers seek to understand a phenomenon by focusing on the total picture rather than breaking it down into variables. The goal is a holistic picture and depth of understanding rather than a numeric analysis of data. After analyzing the data, it was found that the pronunciation of the elision of initial $/ \mathbf{h} /$, final $/ \mathbf{t} /$ and final $/ \mathbf{d} /$ sound realized by the Taiwanese university students were varied. Some still pronounced them and some elided them.
\end{abstract}

Keywords: Sound Elision, Phonology, Pronunciation

\begin{abstract}
Abstrak
Penelitian ini bertujuan untuk mengetahui variasi fonologis dari penghilangan bunyi yang disadari oleh mahasiswa Taiwan dalam melafalkan beberapa frasa bahasa Inggris. Delapan siswa asli Taiwan dipilih untuk mendukung analisis penelitian. Mereka terdiri dari 8 laki-laki dan 8 perempuan dari perguruan tinggi humaniora dan sastra Universitas Chung Chen dan dari fakultas bahasa asing Universitas Asia, Taiwan. Penelitian ini menggunakan desain deskriptif kualitatif. Menurut Ary, Jacob dan Sorensen (2010), peneliti kualitatif berusaha memahami suatu fenomena dengan memusatkan perhatian pada gambaran keseluruhan daripada memecahnya menjadi variabel-variabel. Tujuannya adalah gambaran holistik dan kedalaman pemahaman daripada analisis numerik data. Setelah dilakukan analisis data, ditemukan bahwa pengucapan penghilangan bunyi awal/h/, akhir /t/ dan akhir /d/ yang direalisasikan oleh mahasiswa Taiwan bervariasi. Beberapa masih mengucapkannya dan beberapa menghindarinya.
\end{abstract}

Kata Kunci: Sound Elision, Phonology, Pronunciation

\section{INTRODUCTION}

To speak English fluently needs to pay attention on several distinctive features. Especially to those who are non-native speakers who attempt to interact and communicate to people worldwide. This situation is mostly encountered by both second and foreign language learners (L2/FL). As Maxwell (2010) said that such a situation may pose obstacles for L2/FL learners who aim to improve their pronunciation as well as listening skill. Speaking of foreign language, it is common to find someone speaks English with their accent or way of pronouncing. Taiwanese are one of them. They can be recognized immediately as they speak English because they have a unique way of pronouncing English words and phrases (Maxwell, 2020). According to Anderson and Lynch (1988), there are phonetics and phonological features to be paid attention to speak fluently. One of the phonological 
features that one should pay attention on is elision. Elision is a sound change in which a sound is omitted altogether. Elision is defined as a loss or omission of certain segments or syllables in running speech or colloquial English (Yellop \& Clark, 1990). It could also make a big difference to someone's pronunciation. In addition, Temperly (1987) reported that English as a Foreign Language (EFL) students have a low awareness of connected words together. By having a good knowledge in phonetics and phonology, it can help us to know how to pronounce the words, phrases and even sentences in English correctly.

In relation to the phenomenon above, this study attempts to figure out the variations of sound elision made by Taiwanese university students when they pronounce some of the English phrases. It extends investigation and description of the elision of initial $h$, final $t$ and $d$ sounds made by Taiwanese university students as they pronounce some English phrases from the perspective of non-native speakers. The main investigation is to figure out that whether the elision of the initial $h$, final $t$ and $d$ sounds occur when the subjects of the study, which are literally non-native speakers, pronounce the English phrases casually.

\section{LITERATURE REVIEW Phonology}

Phonology is that part of language which comprises the systematic and functional properties of sound in language. It seeks to discover those systematic properties in the domain of sound structure, and find the regularities and principles behind it both for individual languages and for language in general (Wiese, 2006). In order to categorize English language further, one might also point out that several variations exist within the different varieties. These can, for instance, be of a social or regional nature and can occur between different varieties or within them (Collins \& Mees, 2006). Concerning the latter, the speakers do, nevertheless, have mutual core features by which they can be classified as a group of speakers. In addition, Fromkin et.al (2003) said that the aim of studying the rules of phonology is to give a phonetic information or guideline on how to pronounce a word in a correct way, so the meaning that conveyed from the spoken word can be conveyed correctly. Although the specific rules of phonology differ from language to language, the kind of rules, what they do, and the natural classes they refer to are the same cross-linguistically.

\section{Connected Speech}

Non-native speakers are rarely able to predict which lexical item may or may not appear in a particular situation. They tend to depend almost solely on the sounds which they hear. Learners whose instruction has focused heavily on accuracy suffer a "devastating diminuation of phonetic information at the segmental level when they encounter normal speech" (Dalton \& Seidlhofer, 2001). That is what connected speech deals with. According to Seong (2008), connected speech is a phenomenon in spoken language that collectively includes phonological processes such as reduction, elision, intrusion, assimilation, and contraction.

\section{Elision of Sound}

Elision can be defined as the omission of sounds in connected speech. It is used for the sake of making the pronunciation of sounds easy in connected speech (Crystal, 2003). Yellop \& Clark (1990) stated that elision is a loss or omission of certain segments or syllables in running speech or colloquial English. Moreover, Lillet (2007) explained that elision occurs when a sound is removed from a word. The most common elisions in English are omission of sounds / $t /$ and /d/. Similar to Lillet, Giegerich (1992) said that most common elision in English words is the omission of sounds $/ \mathrm{t} /$ and $/ \mathrm{d} /$ at the word boundary, they are positioned at end of a word before go to the next word. When either the sounds $/ \mathrm{t} /$ or $/ \mathrm{d} /$ is between two other consonant sounds, then the $/ \mathrm{t} / \mathrm{or} / \mathrm{d} / \mathrm{can}$ be omitted. For example, in the phrase "kept going" /kept gəoın/, the $/ \mathrm{t} /$ is between two consonant sounds and can be omitted becomes $/ \mathrm{k} \varepsilon p^{\prime}$ gəom $/$. Another frequent elision is the deletion of $/ \mathrm{h} /$ when it appears in word-initial position after a word boundary, or etc (Williamson, 2015). For example, in the phrase "give him it" /gIv hIm It/. The /h/ is between two consonant sounds and can be omitted becomes /gIv Im It/. He added that unstressed pronouns beginning with $/ \mathrm{h} /$ appear to be susceptible.

\section{The Study \\ Subjects}

The subjects of the study were 8 Taiwanese university students consisting of 4 students of the college of humanities and literature of Chung Chen University and 4 students of the faculty of 
foreign languages of Asia University, Taiwan. Hence, the total subjects were 8 students. Eight native Taiwanese students were chosen because that would be sufficient to support the analysis of the study. They consisted of 8 males and 8 females as well just to make it fair.

\section{METHOD}

The study used a descriptive qualitative design. According to Ary, Jacob and Sorensen (2010), qualitative researchers seek to understand a phenomenon by focusing on the total picture rather than breaking it down into variables. The goal is a holistic picture and depth of understanding rather than a numeric analysis of data.

\section{Data Collection and Analysis}

The data were gained through videos. The subjects recorded themselves reading and pronouncing 18 English phrases which divided into three parts. Part A was 6 phrases consisting of initial $/ \mathbf{h} /$ sound, part $\mathbf{B}$ was 6 phrases consisting of final $/ \mathbf{t} /$ sound, and part $\mathbf{C}$ was also 6 phrases consisting of final $/ \mathbf{d} /$ sound. The data were then be analyzed through listening and taking notes procedures. The videos collected by the writer were listened carefully as they pronounced the phrases one by one and the writer took notes of phonetic transcriptions of the phrases pronounced by the subjects in the videos. By then, the variations of sounds elision could be gained and described.

\section{RESULTS AND DISCUSSIONS}

In order to answer the question of the study, the findings below present the analysis of the data by describing the sounds elision varieties made by the Taiwanese students in pronouncing English phrases.

\section{Initial /h/ Sound}

Here, the phonetic transcriptions were provided into general Bristish English $(\mathrm{BrE})$ and American English (AmE).

Table 1 . The list of elided pronunciations of $/ \mathrm{h} /$ sound realized by the Taiwanese students and their phonetic transciptions

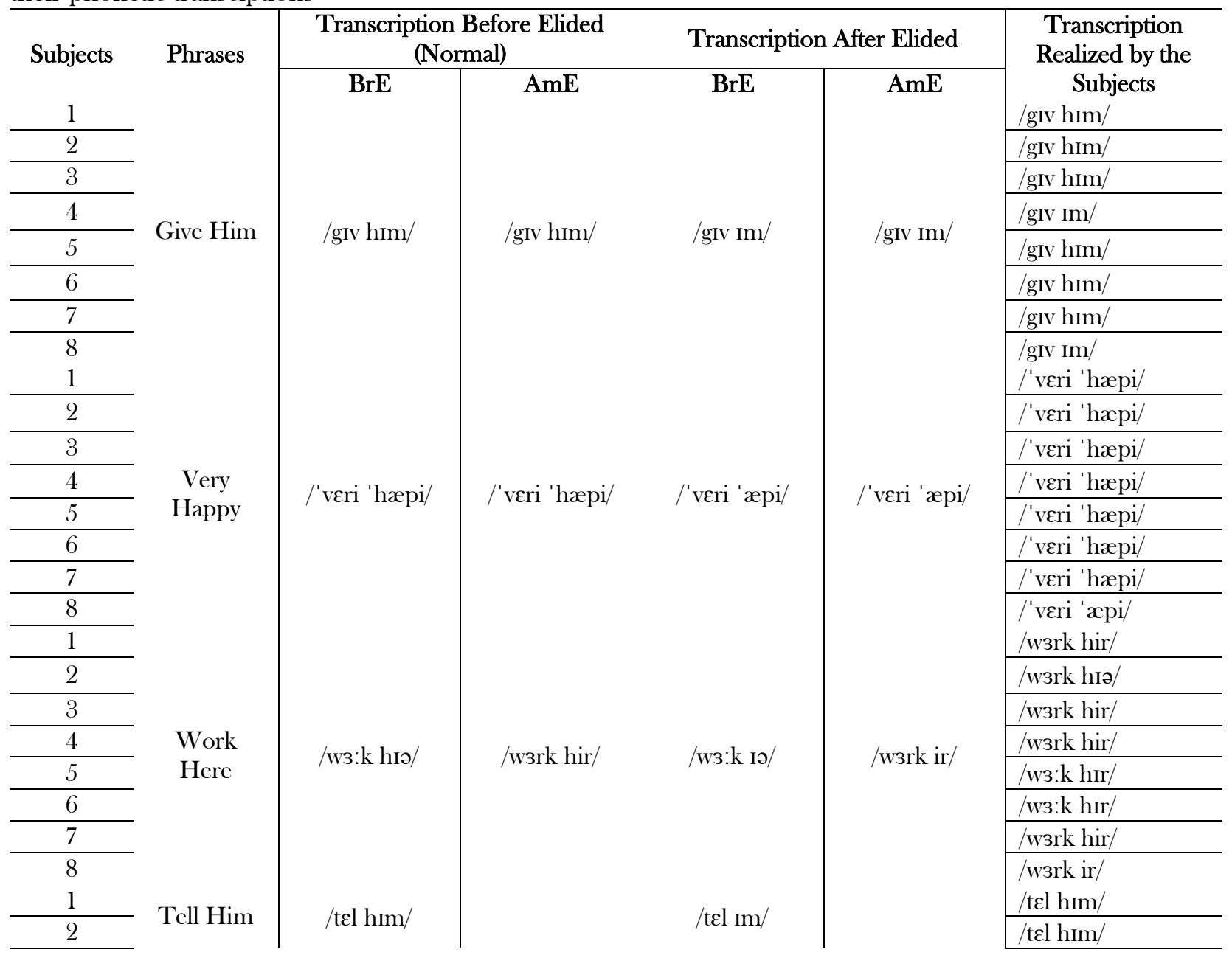




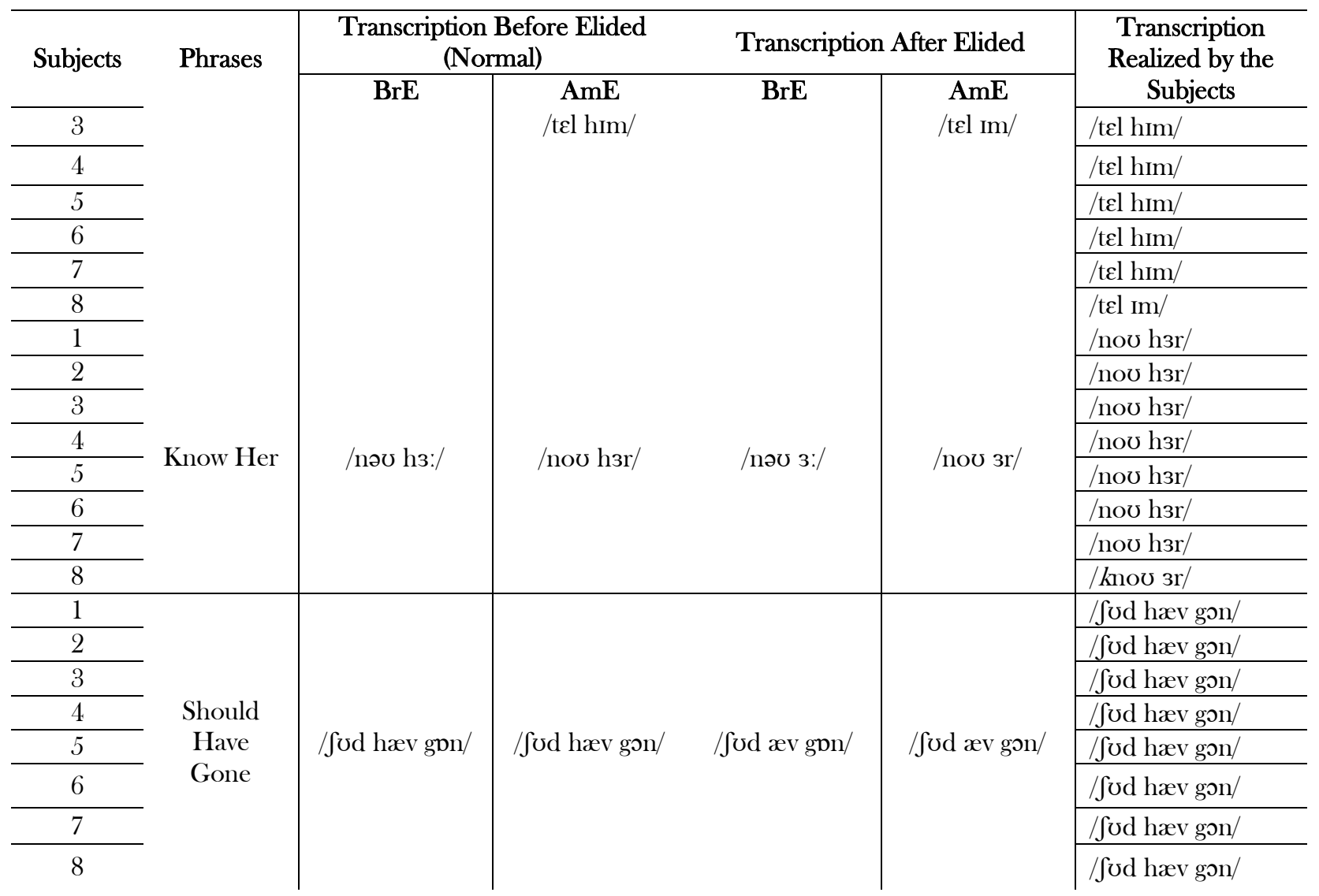

As displayed on the table above, the pronunciation realized by the Taiwanese students were varied. The elisions or omissions of the initial $/ \mathbf{h} /$ sound rarely occured. Most of the subjects still pronounced the $/ \mathrm{h} /$ sound. Even some of them pronounced the phrases in the combination of British and American English. For example, subject 2. She pronounced the phrase "work here" /w3rk hrə/ and combined the American English of the word 'work' with /r/ sound, /w3rk/, and the British English of the word 'here' without/r/ sound, /hro/.

For the first phrase (give him), only one subject elided the $/ \mathbf{h} /$ sound. For the second phrase (very happy), only one subject elided the /h/ sound as well. As for the third phrase (work here), only one subject elided the $/ \mathrm{h} /$ sound as well. For the fourth phrase (tell him), still only one subject elided the $/ \mathbf{h} /$ sound. The fifth phrase (know her), only one subject elided the $/ \mathbf{h} /$ sound. For the last phrase (should have gone), none of the subject elided the $/ \mathbf{h} /$ sound.

\section{Final $/ \mathrm{t} /$ Sound}

Here, the phonetic transcriptions were provided into general Bristish English $(\mathrm{BrE})$ and American English (AmE).

Table 2. The list of elided pronunciations of / $t /$ sound realized by the Taiwanese students and their phonetic transciptions

\begin{tabular}{|c|c|c|c|c|c|c|}
\hline \multirow[t]{2}{*}{ Subjects } & Phrases & \multicolumn{2}{|c|}{$\begin{array}{l}\text { Transcription Before Elided } \\
\text { (Normal) }\end{array}$} & \multicolumn{2}{|c|}{ Transcription After Elided } & \multirow{2}{*}{$\begin{array}{l}\text { Transcription } \\
\text { Pronounced by } \\
\text { the Subjects } \\
\text { /f3rst deI/ }\end{array}$} \\
\hline & \multirow{9}{*}{ First Day } & \multirow{9}{*}{ /f3:st deI/ } & \multirow[t]{2}{*}{$\mathrm{AmE}$} & \multirow[t]{3}{*}{$\mathrm{BrE}$} & \multirow[t]{2}{*}{$\mathrm{AmE}$} & \\
\hline 2 & & & & & & /f3rst deI/ \\
\hline 3 & & & \multirow[t]{7}{*}{ /f3rst deI/ } & & \multirow[t]{7}{*}{ /f3rs deI/ } & /f3rst deI/ \\
\hline 4 & & & & \multirow[t]{6}{*}{ /f3:s deI/ } & & /f3rs deI/ \\
\hline 5 & & & & & & /f3rs deI/ \\
\hline 6 & & & & & & /f3rs deI/ \\
\hline 7 & & & & & & /fars deI/ \\
\hline 8 & & & & & & /f3rs deI/ \\
\hline 1 & & & & & & /best frends/ \\
\hline 2 & \multirow{2}{*}{$\begin{array}{c}\text { Best } \\
\text { Friends }\end{array}$} & \multirow[t]{2}{*}{ /best frendz/ } & \multirow[t]{2}{*}{ /best frendz/ } & \multirow[t]{2}{*}{ /bes frendz/ } & \multirow[t]{2}{*}{ /bes frendz/ } & /best frend/ \\
\hline 3 & & & & & & /best frends/ \\
\hline
\end{tabular}




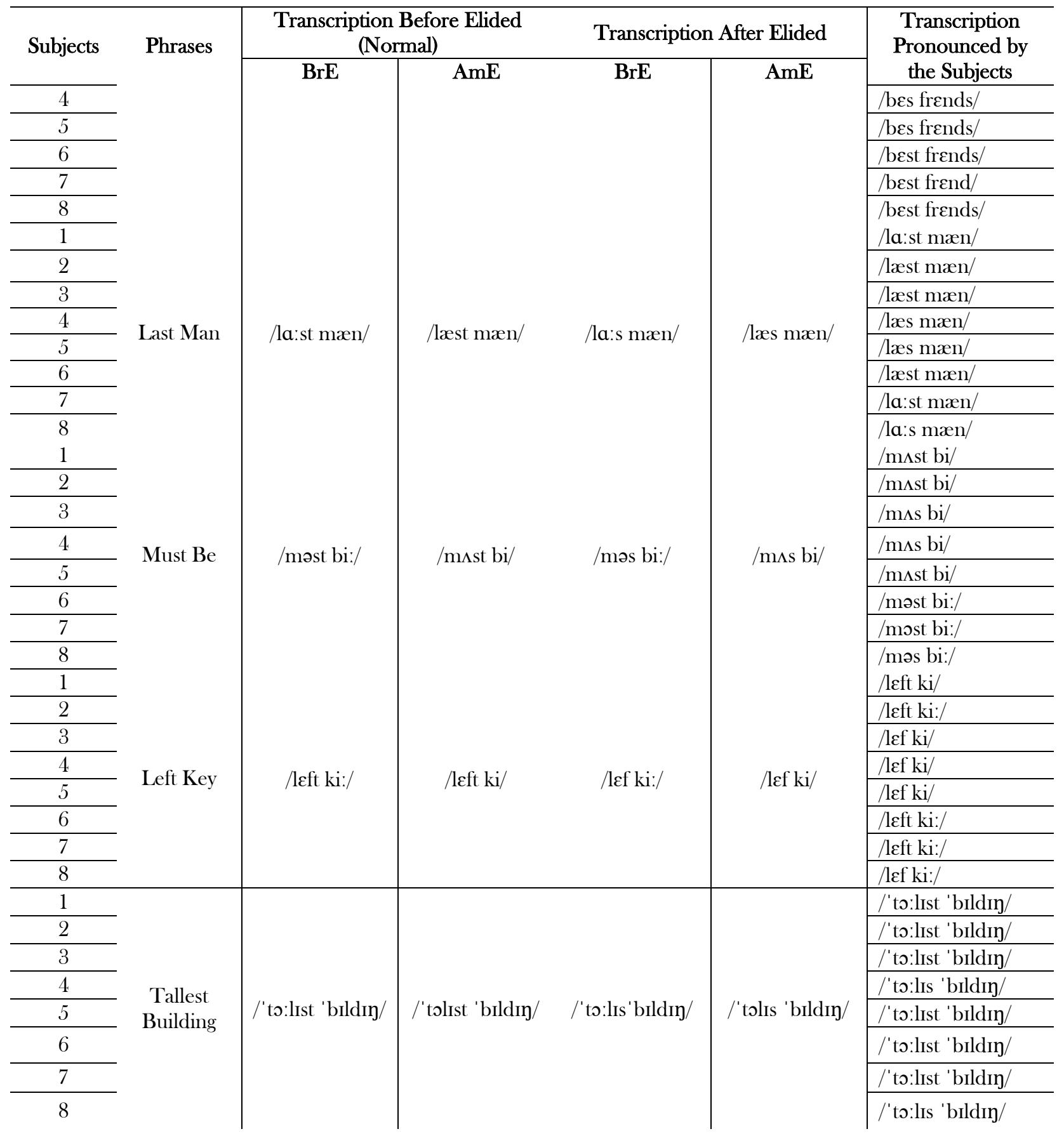

As displayed on the table above, the pronunciation realized by the Taiwanese students were varied. The elisions or omissions of the final $/ \mathbf{t}$ / sound rarely occured. Most of the subjects still pronounced the $/ \mathbf{t} /$ sound.

For the first phrase (first day), only three subjects pronounced the / $t /$ sound. The rest of them elided the sound. For the second phrase (best friends), only three subjects elided the $/ \mathrm{t} /$ sound. As for the third phrase (last man), only three subjects elided the / $\mathbf{t} /$ sound as well, the rest still pronounced the sound. For the fourth phrase (must be), still only one subject elided the $/ \mathbf{t} /$ sound. The fifth phrase (left key), only one subject elided the / $t /$ sound. For the last phrase (tallest building), only one of the subject elided the / $\mathbf{t} /$ sound.

\section{Final /d/ Sound}

Here, the phonetic transcriptions were provided into general Bristish English $(\mathrm{BrE})$ and American English (AmE).

Table 3. The list of elided pronunciations of / $\mathbf{d} /$ sound realized by the Taiwanese students and their phonetic transciptions 


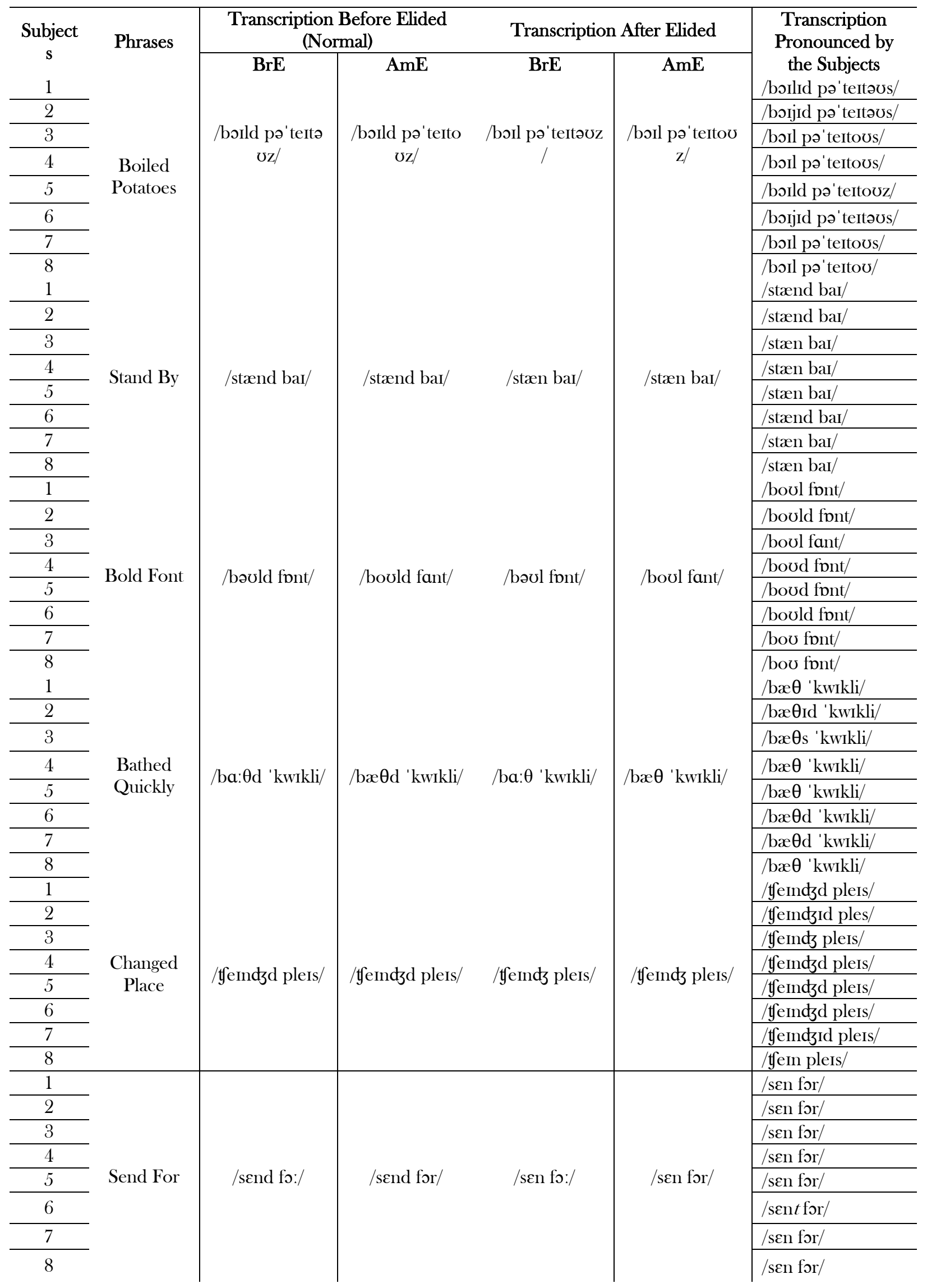

As displayed on the table above, the pronunciation realized by the Taiwanese students were varied. The elisions or omissions of the final /d/ sound rarely occured. Most of the subjects still pronounced the $/ \mathbf{d} /$ sound.

For the first phrase (boiled potatoes), only three subjects pronounced the $/ \mathrm{d} /$ sound. The rest of them elided the sound. For the second phrase (stand by), only three subjects elided the $/ \mathbf{d}$ / sound. As for the third phrase (bold font), only three subjects elided the /d/ sound as well, the rest 
still pronounced the sound. For the fourth phrase (bathed quickly), there were five subjects elided the /d/ sound. The fifth phrase (changed place), only one subject elided the /d/ sound. For the last phrase (send for), almost all of the subjects elided the $/ \mathrm{d} /$ sound, only one particular subject who pronounced not the $/ \mathbf{d} /$ sound but $/ \mathbf{t} /$ sound instead.

\section{CONCLUSION}

After analyzing the data, the conclusion can be drawn as follows: as displayed on the tables above (see table 1, 2, 3), most of the Taiwanese students still pronounced and realized the elision sounds. For the initial /h/ sound, on the first phrase (give him), only one subject elided the $/ \mathbf{h} /$ sound. For the second phrase (very happy), only one subject elided the $/ \mathbf{h} /$ sound as well. As for the third phrase (work here), only one subject elided the $/ \mathbf{h} /$ sound as well. For the fourth phrase (tell him), still only one subject elided the $/ \mathbf{h} /$ sound. The fifth phrase (know her), only one subject elided the /h/ sound. For the last phrase (should have gone), none of the subject elided the $/ \mathbf{h} /$ sound.

For the final $/ \mathbf{t} /$ sound, on the first phrase (first day), only three subjects pronounced the $/ \mathbf{t} /$ sound. The rest of them elided the sound. For the second phrase (best friends), only three subjects elided the $/ \mathbf{t} /$ sound. As for the third phrase (last man), only three subjects elided the $/ \mathbf{t} /$ sound as well, the rest still pronounced the sound. For the fourth phrase (must be), still only one subject elided the / $\mathbf{t}$ / sound. The fifth phrase (left key), only one subject elided the / $\mathbf{t}$ / sound. For the last phrase (tallest building), only one of the subject elided the $/ \mathbf{t} /$ sound.

For the final $/ \mathbf{d} /$ sound, on the first phrase (boiled potatoes), only three subjects pronounced the $/ \mathrm{d} /$ sound. The rest of them elided the sound. For the second phrase (stand by), only three subjects elided the $/ \mathbf{d} /$ sound. As for the third phrase (bold font), only three subjects elided the $/ \mathbf{d} /$ sound as well, the rest still pronounced the sound. For the fourth phrase (bathed quickly), there were five subjects elided the $/ \mathbf{d} /$ sound. The fifth phrase (changed place), only one subject elided the $/ \mathbf{d} /$ sound. For the last phrase (send for), almost all of the subjects elided the /d/ sound, only one particular subject who pronounced not the $/ \mathbf{d} /$ sound but $/ \mathbf{t} /$ sound instead.

\section{REFERENCES}

[1] Anderson, A., Lynch, T. 1988. Listening. In the Series Language and Teaching: A scheme for teacher education. Oxford: Oxford University Press.

[2] Ary, D., Jacob, L., Sorensen, C. 2010. Introduction to Research in Education. $8^{\text {th }}$ Edition. USA: WARDSWORTH Cengage Learning.

[3] Collins, B., Mees, I.M. 2006. Accessing English phonetics and phonology. Handelshøjskolens Forlag

[4] Crystal, D. 2003. A Dictionary of Linguistics and Phonetics (Fifth Edition). Oxford: Blackwell Publishers

[5] Fromkin, V., Rodman, R., Hyams, N. 2003. An Introduction to Language. Boston: Thomson/Heinle.

[6] Giegerich, H.J. 1992. English Phonology: An Introduction. Cambridge: Cambridge University Press

[7] Lillet, A. 2007. Linking of American English. Washington D.C, USA: Seattle Learning Academy

[8] Maxwell, C. 2010. Connected Speech Phenomena: Assimilation, Elision, Linking, and Weakening (A Study of Japanese L2 Learners). Asia University Journal. 66-71

[9] Seong, Y.A. 2008. Evaluating an Instrument for Assessing Connected Speech Performance Using Facets Analysis. Journal of Second Language Studies. 45-101

[10] Wiese, R. 2006. Phonology: Overview. Elsevier Encyclopedia of Language \& Linguistics. 562564

[11] Williamson, G. 2015. Human Communication 101 (English Speech Sounds). USA: SL Therapy Ltd.

[12] Yellop, C., Clark, J. 1990. An introduction to phonetics and phonology. Oxford: Blackwell Publishers Ltd. 